\title{
Cerebellar Granule Cell-Specific and Inducible Expression of Cre Recombinase in the Mouse
}

\author{
Mika Tsujita, ${ }^{1}$ Hisashi Mori, ${ }^{1}$ Masahiko Watanabe, ${ }^{2}$ Misao Suzuki, ${ }^{3}$ Jun-ichi Miyazaki, ${ }^{4}$ and \\ Masayoshi Mishina ${ }^{1,5}$ \\ 1Department of Molecular Neurobiology and Pharmacology, School of Medicine, University of Tokyo, Tokyo 113-0033, \\ Japan, ${ }^{2}$ Department of Anatomy, Hokkaido University, School of Medicine, Sapporo 060-8638, Japan, ${ }^{3}$ Center for Animal \\ Resources and Development, Kumamoto University, Kumamoto 860-0811, Japan, ${ }^{4}$ Department of Nutrition and \\ Physiological Chemistry, Osaka University Medical School, Osaka 565-0871, Japan, and 5CREST, Japan Science and \\ Technology Corporation, Saitama 332-0012, Japan
}

To develop a cell type-specific and temporal regulation system of gene targeting in the cerebellum, we used the NMDA-type glutamate receptor GluR $\epsilon 3$ subunit gene and Cre recombinaseprogesterone receptor fusion (CrePR) gene in combination. Injection of the CrePR gene placed under the control of the 10 kb 5 ' region of the GluR $\epsilon 3$ gene into C57BL/6 eggs yielded the ECP25 line that strongly expressed the CrePR mRNA selectively in the granule cells of the cerebellum. Using a transgenic mouse carrying a reporter gene for Cre-mediated recombina- tion, we showed that antiprogestins could induce the recombinase activity of CrePR protein in the cerebellar granule cells of the ECP25 line. Thus, the established mouse line will provide a valuable tool to investigate the mechanism of cerebellar function by manipulating molecules in the temporally regulated and granule cell-specific manner.

Key words: Cre recombinase; antiprogestin; cerebellum; cerebellar granule cell; gene targeting; NMDA receptor GluR $\epsilon 3$ subunit; progesterone receptor; transgenic mouse
The pattern of intrinsic neural connections in the cerebellum is known in considerable detail (Altman and Bayer, 1997). The laminar arrangements of cells in the cerebellar cortex and the microcircuitry are highly specific and uniform. The number of cell types in the cerebellum is small despite a very large number of neurons. The two main cerebellar inputs are the mossy fibergranule cell to Purkinje cell and climbing fiber to Purkinje cell systems. The mossy fibers bring vestibular, somatic, visual, and auditory sensory information and signals from sensorimotor cerebral cortex, whereas the approximately one-to-one climbing fiber to Purkinje cell system arises exclusively from neurons of the inferior olive. Lesion studies have established the important roles of the cerebellum in the regulation of fine motor control, motor learning, and memory (Thach et al., 1992; Thompson and Krupa, 1994; du Lac et al., 1995). The wealth of knowledge on the neural circuits in the cerebellum led to the models and theories of cerebellar function (Marr, 1969; Albus, 1971). Cerebellar synapses show adaptive plasticity including long-term depression (LTD) and long-term potentiation (LTP) at the granule cellPurkinje cell synapse and LTP at the mossy fiber-interpositus nucleus synapse (Ito et al., 1982; Racine et al., 1986; Sakurai, 1987). Furthermore, recent studies suggest the involvement of the cerebellum in cognitive processes (Thach, 1996; Desmond and

\footnotetext{
Received Aug. 5, 1999; revised Sept. 7, 1999; accepted Sept. 17, 1999.

We thank K. Kobayashi and Y. Yoshihara for help in breeding mice, Dr. I. N. Maruyama for the gift of plasmid pCRE1, and Dr. B. W. O'Malley for the gift of plasmid RSV-hPRB891. The antiprogestins Org 31376 and Org 31806 were provided by N. V. Organon Scientific Development Group.

Correspondence should be addressed to Masayoshi Mishina, Department of Molecular Neurobiology and Pharmacology, School of Medicine, University of Tokyo, Hongo 7-3-1, Bunkyo-ku, Tokyo 113-0033, Japan. E-mail: mishina@ m.u-tokyo.ac.jp.

Copyright (C) 1999 Society for Neuroscience $0270-6474 / 99 / 1910318-06 \$ 05.00 / 0$
}

Fiez, 1998). These features make the cerebellum an ideal system to study the molecular mechanism of brain function.

A powerful approach is the mutagenesis by homologous recombination in embryonic stem cells (Capecchi, 1989). Mutant mice deficient in metabotropic glutamate receptor 1 (mGluR1), glutamate receptor channel $\delta 2$ subunit (GluR $\delta 2$ ), or glial fibrillary acidic protein, produced by conventional gene targeting, exhibited the impairment of LTD at the granule cell-Purkinje cell synapse and motor learning (Aiba et al., 1994; Kashiwabuchi et al., 1995; Shibuki et al., 1996; Kishimoto et al., 1998), although the physiological significance of presynaptic LTP at the granule cell-Purkinje cell synapse remains unknown (Storm et al., 1998). Transgenic mouse expressing protein kinase $\mathrm{C}$ inhibitor under the Purkinje cell-specific L7 promoter exhibited the impaired cerebellar LTD and adaptation of the vestibulo-ocular reflex (De Zeeuw et al., 1998). However, these mice suffered persistent multiple innervation of Purkinje cells by climbing fibers (Kashiwabuchi et al., 1995; Kano et al., 1997; De Zeeuw et al., 1998). Thus, it is important to develop a cell type-specific and temporally regulated gene targeting. One elegant way is the application of bacteriophage P1 Cre recombinase and its target sequence loxP in the mouse (Gu et al., 1993, 1994; Tsien et al., 1996; Brocard et al., 1997; Kellendonk et al., 1999). Here, we report the development of a cerebellar granule cell-specific and inducible genetargeting system using the NMDA-type glutamate receptor GluR $\epsilon 3$ subunit gene and Cre recombinase-progesterone receptor fusion (CrePR) gene in combination.

\section{MATERIALS AND METHODS}

Construction of CrePR gene and ECP expression vector. The 69 bp SalIAgeI fragment encoding the initial methionine, the nuclear location signal (NLS) of SV40 large T antigen (Kalderon et al., 1984), and the amino acid residues $2-13$ of Cre recombinase was amplified by PCR using pCRE1 (Maruyama and Brenner, 1992) as a template. The 69 bp SalI- 
Age I PCR fragment, the $1.0 \mathrm{~kb}$ Age I-BspHI and $69 \mathrm{bp} B s p \mathrm{HI}-E c o \mathrm{RI}$ fragments from pCRE1, and the $2.7 \mathrm{~kb}$ SalI-EcoRI fragment from pBluescript II SK (Stratagene, La Jolla, CA) were ligated to yield pNCre. The $0.2 \mathrm{~kb} B s p \mathrm{HI}-H p h \mathrm{I}$ fragment encoding the $\mathrm{C}$ terminal 22 amino acids of Cre recombinase fused to the amino acid residues 640-674 of the human progesterone receptor was amplified by two-step PCR (Ho et al., 1989) using pNCre and RSV-hPRB891 (provided by Dr. B. W. O'Malley, Baylor College of Medicine, Houston, TX) as templates. The $1.0 \mathrm{~kb}$ SalI(blunted)-BspHI fragment from pNCre, the $0.2 \mathrm{~kb} B s p \mathrm{HI}-H p h \mathrm{I}$ PCR fragment, the $0.7 \mathrm{~kb} H$ phI-SmaI fragment from RSV-hPRB891, the $16 \mathrm{bp}$ SmaI-XbaI fragment from pBluescript II SK, the $5.5 \mathrm{~kb} X b a \mathrm{I}-B s t \mathrm{XI}$ fragment from pEF-BOS (Mizushima and Nagata, 1990), and the $8 \mathrm{bp}$ $B s t \mathrm{XI}$ adaptor were ligated to yield pCrePR. The $1.3 \mathrm{~kb}$ HindIII-XbaI fragment from pEF-BOS, the 39 bp $X b a I-E c o R I$ oligonucleotide containing the loxP sequence, the $1.4 \mathrm{~kb}$ of EcoRI-BamHI fragment from pGK2Neo (Yagi et al., 1993), the 39 bp BamHI-HincII oligonucleotide containing the loxP sequence, the $3.5 \mathrm{~kb}$ BstEII (blunted)-Bam HI fragment from phspPTlacZpA (Kothary et al., 1989), and the $2.7 \mathrm{~kb}$ HindIIIBam HI fragment from pBluescript II SK were ligated to yield pNloxZ.

The region between the $X b a I$ and HincII sites of pBluescript II SK was deleted, and the 62 bp oligonucleotide carrying NotI-NheI-SalI-KpnIHindIII-Eco RV-EcoRI-KpnI-SalI-NheI-NotI sites was inserted into the NotI site of the modified plasmid to yield pBSKN. The 79 bp PstI-AgeI fragment containing the $16 \mathrm{bp}$ GluR $\epsilon 3$ gene segment upstream of the initial methionine codon and the DNA segment encoding the $\mathrm{N}$ terminal 21 amino acids of the CrePR was amplified by two-step PCR using the $11.5 \mathrm{~kb}$ EcoRI fragment from $\lambda$ GRE3E1 (Nagasawa et al., 1996) and pNCre as templates. The $10 \mathrm{~kb}$ EcoRI-Pst I fragment from $\lambda$ GRE3E1, the 79 bp PstI-AgeI PCR fragment, the $2.4 \mathrm{~kb}$ AgeI-EcoRI fragment from $\mathrm{pCrePR}$, and the $2.7 \mathrm{~kb}$ EcoRI fragment of pBSKN were ligated to yield $\mathrm{pECP}$.

Cell culture. NIH3T3 cells were cultured in DMEM containing 10\% fetal calf serum. Four micrograms of pCrePR, $4 \mu \mathrm{g}$ of pNloxZ, and $0.2 \mu \mathrm{g}$ of pSTneoB (Katoh et al., 1987) were linearized by ScaI, SalI, and XhoI, respectively, and transfected by electroporation (Gene Pulser, set $960 \mu \mathrm{F}$, $350 \mathrm{~V}$; Bio-Rad, Hercules, CA) into $2 \times 10^{6}$ cells in $0.6 \mathrm{ml}$ of $25 \mathrm{~mm}$ HEPES-buffered saline, $\mathrm{pH}$ 7.05. Stable transformants were selected in the medium containing $700 \mu \mathrm{g} / \mathrm{ml} \mathrm{G} 418$. The isolated cell lines were incubated with or without $1 \mu \mathrm{M}$ Org 31376 or Org 31806 for $2 \mathrm{~d}$. After fixation in $9.6 \mathrm{~mm}$ PBS, $\mathrm{pH} 7.4$, containing $2 \%$ formaldehyde and $0.2 \%$ glutaraldehyde, cells were stained for $\beta$-galactosidase activity overnight at $37^{\circ} \mathrm{C}$ in PBS containing $5 \mathrm{~mm}$ potassium hexacyanoferrate (III), $5 \mathrm{~mm}$ potassium hexacyanoferrate (II), $2 \mathrm{mM} \mathrm{MgCl}_{2}$, and $1 \mathrm{mg} / \mathrm{ml}$ 5-bromo-4chloro-3-indolyl- $\beta$-D-galactoside. After the staining, cells were counterstained in $4 \mathrm{~mm}$ sodium acetate buffer, $\mathrm{pH} 3.5$, containing $1 \%$ of neutral red. $\beta$-Galactosidase activities in the cytoplasmic extracts were measured using an assay system (Promega, Madison, WI).

Generation of CrePR transgenic mice. The $12.5 \mathrm{~kb}$ Not I fragment from pECP was fractionated by electrophoresis on a $0.8 \%$ GTG agarose (TaKaRa, Tokyo, Japan) gel, purified by silica matrix (Glassmilk; Bio 101, La Jolla, CA) and eluted in $1 \mathrm{~mm}$ Tris- $\mathrm{HCl}$ buffer, $\mathrm{pH}$ 8.0, containing $0.1 \mathrm{~mm}$ EDTA. The DNA fragment $(30 \mu \mathrm{g} / \mathrm{ml})$ was microinjected into pronuclei of C57BL/6 fertilized one-cell embryos. Injected embryos were transplanted into the pseudopregnant female mice. Sixty-eight founder mice were produced. Breeding and maintenance of mice were performed under institutional guidelines.

Transgenic mice carrying the CrePR gene were identified by Southern blot hybridization analysis of genomic DNA prepared by tail biopsy or by PCR using primers CreP1 (5'-GCCTGCATTACCGGTCGATGCAACG-3') and CreP2 (5'-AAATCCATCGCTCGACCAGTTTAGTTACCC $\left.-3^{\prime}\right)$. Genomic DNA was digested with EcoRI and hybridized with the $1.2 \mathrm{~kb}$ Sall-EcoRI fragment from pNCre (probe A) and the $0.2 \mathrm{~kb}$ EcoRI-ApaI fragment from pBKSA $\epsilon 3$ (Kutsuwada et al., 1992) (probe B).

Analysis of CrePR $m R N A$. Reverse transcription (RT)-PCR analysis of CrePR mRNA was performed by treatment with reverse transcriptase of total cerebellar RNA purified using RNeasy kit (Qiagen, Hilden, Germany) and amplification of $241 \mathrm{bp}$ CrePR fragment with PCR primers 5'-GATATGGCCCGCGCTGGAGTTTCAA-3' (CPRP1) and 5'-GTGAATCTCTGGCTTAGGGCTTGGC-3' (CPRP2).

Northern blot hybridization analysis was performed as described previously (Mori et al., 1994) using $10 \mu \mathrm{g}$ of total RNA extracted from the cerebellum and forebrain by the acid guanidium thiocianate-phenolchloroform extraction method (Chomczynski and Sacchi, 1987) and probe A.

In situ hybridization analysis was performed using Cre recombinase-

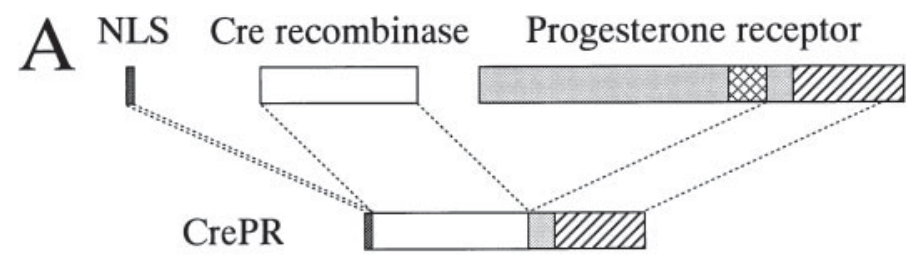

B
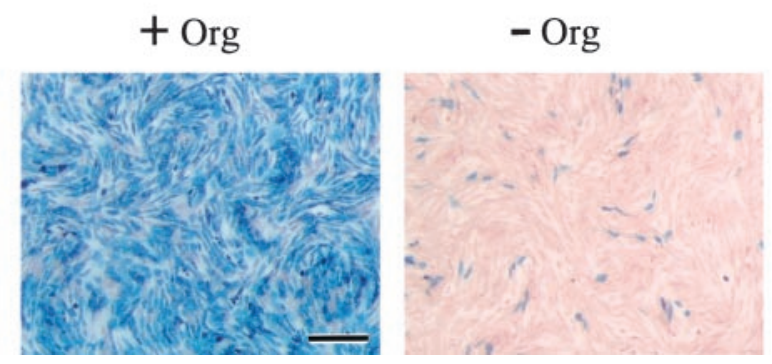

Figure 1. Inducible activation of CrePR by antiprogestins. $A$, Structure of CrePR. CrePR protein consists of the NLS of SV40 T antigen, Cre recombinase, and the ligand-binding domain of the human progesterone receptor lacking the $\mathrm{C}$ terminal 42 amino acids. The hatched and crosshatched regions represent the ligand binding and DNA binding domains of the progesterone receptor, respectively. $B$, Induction of Cre recombinase activity by Org 31806 in NIH3T3 cells. Cell lines transformed with CrePR gene and pNloxZ reporter gene were stained for $\beta$-galactosidase activity after incubation with or without $1 \mu \mathrm{M}$ Org 31806 for $48 \mathrm{hr}$. Scale bar, $200 \mu \mathrm{m}$.

specific oligonucleotide probe CrePR898 (5'-GAAACTCCAGCGCGGGCCATATCTCGCGCGGTCCCGACACGGGCA-3') and GluR $\epsilon 3$ specific oligonucleotide probe $\epsilon 3 \mathrm{~A}$ as described previously (Kutsuwada et al., 1992; Watanabe et al., 1993). Brains were removed from the skulls of mice under inhalation and frozen in powdered dry ice. Parasagittal brain sections $(20 \mu \mathrm{m})$ were prepared using the cryostat and mounted on glass slides. Sections were counterstained with methyl green-pyronin.

Induction of CrePR recombinase activity in vivo by antiprogestins. CrePR transgenic mice were mated with CAG-CAT-Z11 mice (Araki et al., 1995), and offspring were genotyped by PCR. Mice at postnatal day (P) 33-42 were injected with antiprogestin Org 31376 or Org 31806 dissolved in sesame oil $(1.3 \mathrm{mg} / 200 \mu \mathrm{l})$ in the peritoneum for $4-10$ consecutive days. Control mice were injected $200 \mu \mathrm{l}$ of sesame oil. Three to $10 \mathrm{~d}$ after the injection, mice were deeply anesthetized with Nembutal and were fixed transcardially with $4 \%$ paraformaldehyde in PBS. Brains were post-fixed in the same fixative for an additional $2 \mathrm{hr}$ at $4^{\circ} \mathrm{C}$ and dipped in PBS containing $30 \%$ sucrose for $1 \mathrm{~d}$. Parasagittal brain sections of $1 \mathrm{~mm}$ were prepared, and histochemical detection of $\beta$-galactosidase was performed for $18 \mathrm{hr}$ as described above. After the staining, cryostat brain sections $(50 \mu \mathrm{m})$ were prepared and mounted on glass slides.

\section{RESULTS}

To develop a cell type-specific and temporal regulation system of gene targeting in the cerebellum, we used the NMDA receptor GluR $\epsilon 3$ subunit gene and Cre recombinase-progesterone receptor fusion gene in combination. The GluR $\epsilon 3$ gene is strongly expressed in the cerebellar granule cells, whereas weak expression is detected in the thalamus and olfactory bulb (Kutsuwada et al., 1992; Monyer et al., 1992; Watanabe et al., 1992, 1994). Thus, the GluR $\epsilon 3$ subunit gene promoter would be useful for granule cell-specific expression in the cerebellum. For temporal regulation of gene targeting, we fused Cre recombinase to the ligandbinding domain of the human progesterone receptor lacking the C terminal 42 amino acids (Vegeto et al., 1992) so that the Cre recombinase activity became inducible by synthetic antagonists of the progesterone receptor as described by Kellendonk et al. (1996) (Fig. 1A). To confirm that the Cre recombinaseprogesterone receptor fusion protein CrePR is functional, human EF-1 $\alpha$ promoter-driven CrePR gene was transfected into 
Figure 2. Isolation and characterization of the ECP25 transgenic mouse line carrying the CrePR gene under the control of the GluR $\epsilon 3$ gene promoter. A, Structure of cerebellar granule cell-specific expression vector of CrePR gene. The structure of GluR $\epsilon 3$ cDNA and GluR $\epsilon 3$ gene are schematically shown above the expression vector. Coding sequence of GluR $\epsilon 3 \mathrm{cDNA}$ is shown by a box. Putative transmembrane or channel-forming segments M1-M4 are indicated. Exons of the GluR $\epsilon 3$ gene are shown by filled boxes. The ECP expression vector linearized by NotI consists of the $10 \mathrm{~kb} 5^{\prime}$ region of the GluR $\epsilon 3$ gene, the $1.9 \mathrm{~kb}$ CrePR gene (hatched $b o x)$, and the $0.6 \mathrm{~kb}$ hG-CSF polyadenylation signal sequence $(p A)$. Cross-hatched bars indicate the probes used for hybridization analyses. $E, E c o$ RI; $N, N o t I$. $B$, Expression of CrePR mRNA in the cerebellum of the ECP25 line. Total RNA $(10 \mu \mathrm{g})$ prepared from the forebrain $(\mathrm{Fb})$ and cerebellum $(\mathrm{Cb})$ of ECP25 mouse at P28 was electrophoresed and hybridized with probe A. The arrowhead indicates the CrePR mRNA. $C$, Integration of the CrePR gene in the genome of the ECP25 line. Genomic DNA (2 $\mu \mathrm{g}$ each) from the wild-type $(W T)$ and ECP25 mice was digested with EcoRI, electrophoresed, and hybridized with probes $\mathrm{A}$ and $\mathrm{B}$. The intact ECP vector $(12.5 \mathrm{~kb})$ is indicated by the filled arrowhead, and endogenous GluR $\epsilon 3$ gene fragment hybridized with probe B $(11.5 \mathrm{~kb})$ by the open arrowhead. The $>20 \mathrm{~kb}$ fragment hybridized with both probes and the $6.6 \mathrm{~kb}$ fragment hybridized with probe A represent incomplete copies of the ECP vector.
A

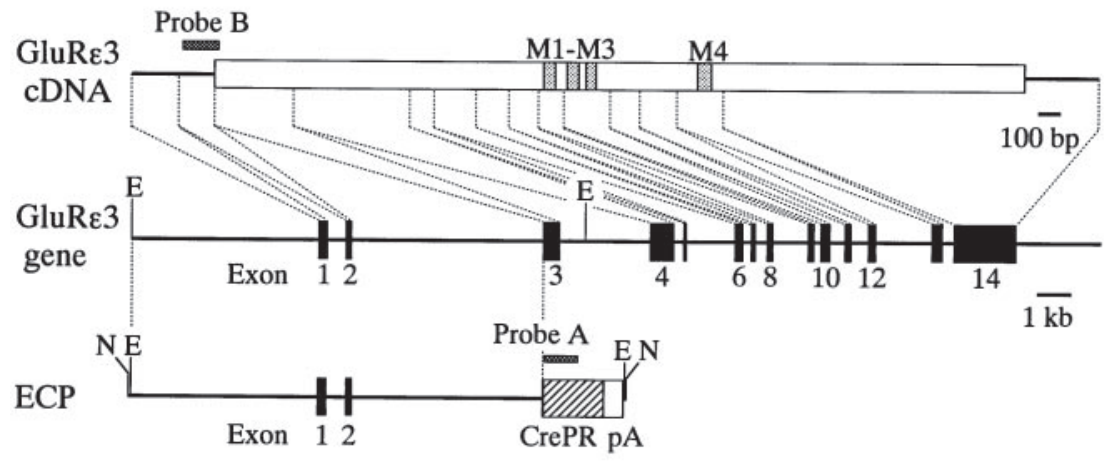

B

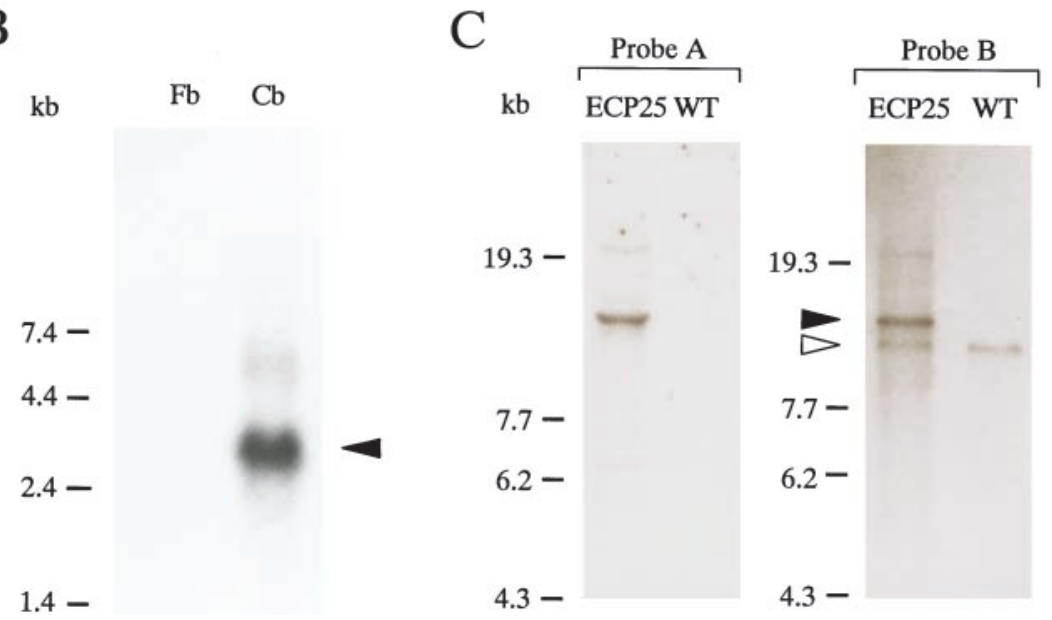

NIH3T3 cells together with a reporter gene (pNloxZ), in which the expression of $\beta$-galactosidase depended on recombination mediated by Cre recombinase. We selected several stable transformants with little $\beta$-galactosidase expression. Treatment of these cells with synthetic steroids Org 31806 and Org 31376 (Bakker et al., 1990; Vegeto et al., 1992) induced the expression of $\beta$-galactosidase, indicating that the Cre recombinase activity of the constructed fusion protein is inducible by these antiprogestins (Fig. 1B).

We chose the $5^{\prime}$ region of the GluR $\epsilon 3$ subunit gene to express Cre recombinase selectively in cerebellar granule cells. Figure $2 A$ schematically shows the mouse GluR $\epsilon 3$ gene (Nagasawa et al., 1996). The $5^{\prime}$ upstream region contains consensus sequences of $\mathrm{Sp} 1$ and EGR-1 binding motifs and some repetitive sequences. The coding sequence of CrePR protein was inserted into the translational initiation codon of the mouse GluR $\epsilon 3$ gene. We injected the CrePR gene under the control of the $10 \mathrm{~kb} 5^{\prime}$ region of the GluR $\epsilon 3$ gene (ECP expression vector) into eggs of C57BL/6 strain. Among 19 transgenic lines, two lines showed strong signals in RT-PCR analysis of cerebellar RNA, and six lines exhibited weak signals. RNA blot hybridization analysis showed that one line (ECP25) strongly expressed the CrePR mRNA in the cerebellum (Fig. $2 B$ ). The size of the major RNA species $(\sim 3.3 \mathrm{~kb})$ is as expected for the CrePR mRNA. There was no detectable expression in the forebrain. Southern blot hybridization analysis showed that the ECP25 line contained approximately three copies of intact ECP vector $(12.5 \mathrm{~kb})$ in the genome (Fig. 2C). The integrated vector DNA in the ECP25 line was stable for at least three generations.
Further in situ hybridization analysis with an oligonucleotide probe indicated that the expression of the CrePR mRNA was restricted to the granular layer of the cerebellum (Fig. 3A, top). There were no detectable CrePR mRNA signals in the thalamus and the olfactory bulb in which the GluR $\epsilon 3$ mRNA is weakly expressed (Kutsuwada et al., 1992; Watanabe et al., 1992) (Fig. $3 A$, bottom). Bright-field microscopic examination showed that strong hybridization signals for the CrePR mRNA were exclusively in the granule cells of the cerebellum (Fig. $3 B$ ). There were little signals in the Purkinje cells. These analyses showed that the strong expression of CrePR mRNA in the ECP25 line was highly specific to the cerebellar granule cells. Notably, the strong CrePR mRNA expression was found in most of the lobules of the cerebellar cortex (lobules I-IX), but little expression was detected in lobule X and a caudal part of lobule IX (Fig. $3 A$ ).

To examine whether CrePR fusion recombinase is inducible and functional in vivo, we crossed the ECP25 line with the CAG-CAT-Z11 transgenic mouse as a reporter for Cre recombinase activity. The reporter mouse carried the chicken $\beta$-actin gene (CAG) promoter, the chloramphenicol acetyltransferase (CAT) gene flanked by two loxP sites and the $\beta$-galactosidase gene in sequence (Araki et al., 1995). Recombination between loxP sites would delete the CAT gene and join the strong CAG promoter and the $\beta$-galactosidase gene, leading to the expression of the latter (Fig. $4 A$ ). We confirmed by staining that all brain regions could express $\beta$-galactosidase activity in the CAG-CATZ11 line (Fig. 4B). After crossing, mice with both the CrePR and CAG-CAT-Z genes were selected. We injected $1.3 \mathrm{mg}$ of Org 31806 per day into the peritoneum of mice for 4 consecutive days. 

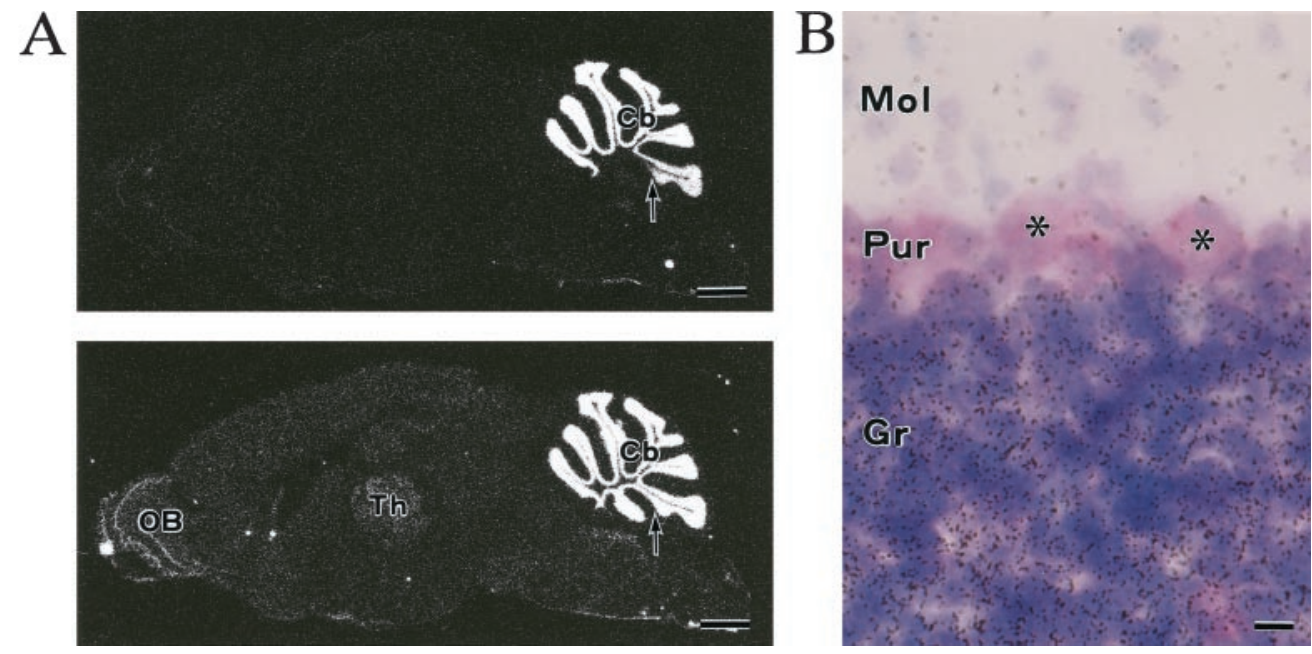

Figure 3. Cerebellar granule cellspecific expression of CrePR mRNA in the ECP25 line. $A$, Negative images of x-ray film autoradiograms showing CrePR mRNA (top) and GluRe3 mRNA (bottom) in parasagittal brain sections. Scale bar, $1 \mathrm{~mm}$. Arrows indicate the border of CrePR mRNA expression in the granular layer of lobule IX. $\mathrm{Cb}$, Cerebellum; Th, thalamus; $O B$, olfactory bulb. $B$, Bright-field micrograph at a higher magnification showing the localization of hybridization signals of CrePR mRNA in cerebellar granule cells. Sections were counterstained with methyl greenpyronin. Scale bar, $10 \mu \mathrm{m}$. Asterisks indicate the cell body of Purkinje cells. Gr, Granule cell layer; Mol, molecular layer; Pur, Purkinje cell layer.
Three days after injection, brain slices were prepared and stained for $\beta$-galactosidase activity. Uninjected littermates were also stained as controls. As shown in Figure $4 C$, the granular layer of the cerebellum from mice injected with Org 31806 exhibited strong staining, except for lobules IX and X. At a higher magnification, the staining for $\beta$-galactosidase was observed in the granule cells but not in Purkinje cells (Fig. 4E). Most of the granule cells in lobules I-V III seemed to show staining. The staining was diffuse because the expression of $\beta$-galactosidase in the tester mouse was cytoplasmic. By examining randomly sampled photographs, we estimated that $\sim 90 \%$ of cells in the granular layer showed diff use staining in lobules I-VIII. The staining in other regions was as low as that in the uninjected control mice (Fig. $4 D$ ). There was a weak staining in the granular layer of the cerebellum of control mice, which may represent the residual recombinase activity of CrePR without induction or its activation by endogenous ligands. A slight background staining in the entire brain was observed in the control mice, as well as in mice carrying the reporter gene alone. These results suggest that functional Cre recombinase can be induced specifically in the cerebellar granule cells in the ECP25 line.

\section{DISCUSSION}

Here, we have established the ECP25 mouse line with which one can induce Cre mediated-recombination in the cerebellar granule cell-specific manner. The combination of the specific GluR $\epsilon 3$ promoter and induction of CrePR recombinase by antiprogestins yields this highly selective conditional knock-out system. We have shown that the CrePR gene under the control of the $5^{\prime}$ region of the mouse GluRe3 gene (Nagasawa et al., 1996) is expressed exclusively in the cerebellar granule cells of the ECP25 line. There is no expression in the thalamus and the olfactory bulb in which the GluR $\epsilon 3$ gene is weakly expressed (Kutsuwada et al., 1992; Watanabe et al., 1992). The DNA segment used to direct
A
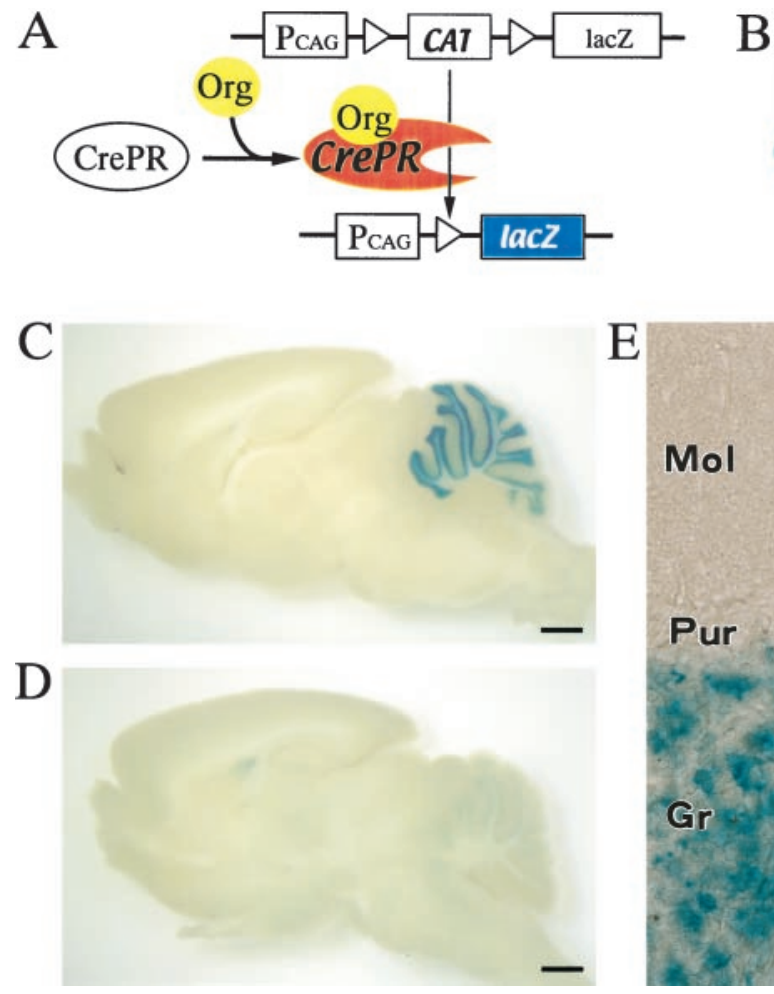

$\mathrm{E}$

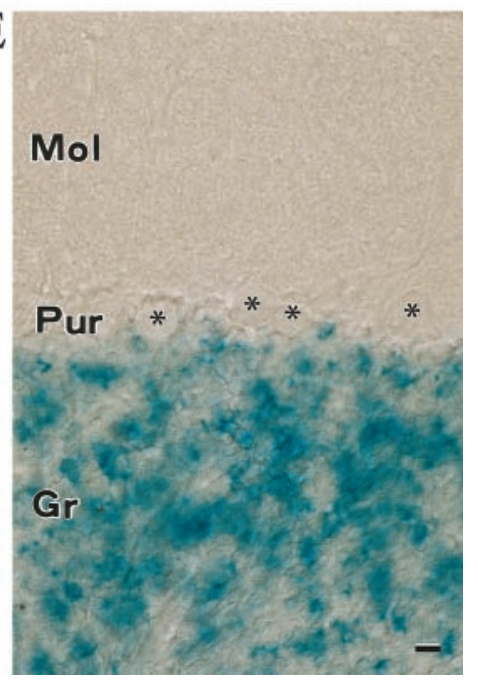

Figure 4. Inducible expression of functional Cre recombinase selectively in cerebellar granule cells of the ECP25 line. A, Schema of Cre recombinase assay in vivo. Synthetic steroid Org 31806 activates the recombinase of CrePR protein in the granule cells of the cerebellum. The activated CrePR mediates recombination between two loxP target sites flanking the CAT gene of the reporter, leading to the expression of $\beta$-galactosidase gene (lacZ) by $\mathrm{CAG}$ promoter $\left(P_{C A G}\right)$. $B$, Staining for $\beta$-galactosidase of a parasagittal brain section from a CAG-CAT-Z11 mouse crossed with a mouse expressing Cre recombinase early in the development (K. Nakamura, H. Mori, and M. Mishina, unpublished observations). Scale bar, $1 \mathrm{~mm}$. $C$, Localization of $\beta$-galactosidase expression in the granular layer of the cerebellum of an antiprogestin-injected mouse with the CrePR and CAG-CAT-Z genes. Parasagittal brain sections from the transgenic mice injected with Org 31806 for 4 consecutive days were stained for $\beta$-galactosidase $3 \mathrm{~d}$ after injection. Scale bar, $1 \mathrm{~mm}$. $D$, Staining for $\beta$-galactosidase of a parasagittal brain section from a control uninjected mouse with the CrePR and CAG-CAT-Z genes. Scale bar, $1 \mathrm{~mm}$. E, Highpower micrograph showing the selective expression of $\beta$-galactosidase in the cerebellar granule cells of an antiprogestin-injected mouse with the CrePR and CAGCAT-Z genes. Scale bar, $10 \mu \mathrm{m}$. Asterisks indicate the cell body of Purkinje cells. Gr, Granule cell layer; Pur, Purkinje cell layer; Mol, molecular layer. 
the CrePR expression contains the $4.7 \mathrm{~kb}$ segment upstream of the transcription start site and the $5.3 \mathrm{~kb} 5^{\prime}$ region of the GluRe3 gene consisting of exons $1-3$ and introns 1 and 2 . This region used may lack the segments necessary for the expression in the thalamus and olfactory bulb. Suchanek et al. (1997) showed that the 0.4 $\mathrm{kb}$ DNA segment upstream of the transcription start site of the GluR $\epsilon 3$ gene had a general promoter activity. On the other hand, the $1.0 \mathrm{~kb}$ segment downstream of the transcription start site directed the expression in cerebellar granule cells with weaker additional expression in other brain regions. Thus, these authors suggest that there is a basal promoter in the $5^{\prime}$ upstream region of the GluR $\epsilon 3$ gene and that the downstream region may contain negative regulatory elements that determine the specific expression of GluR $\epsilon 3$ gene. Notably, the strong CrePR expression was found in most of the lobules of the cerebellar cortex (lobules I-IX), but little expression was detected in lobule $\mathrm{X}$ and a caudal part of lobule IX. These regions receive direct vestibular projection constituting the vestibulocerebellum that is phylogenetically the oldest component of the cerebellum (Altman and Bayer, 1997). The earliest expression of GluR $\epsilon 3$ gene during development of the cerebellum appears in the lobules IX and X (Watanabe et al., 1992). The regulation of the GluR $\epsilon 3$ gene expression may differ depending on lobules of the cerebellum.

$\mathrm{Gu}$ et al. (1993) demonstrated the successful application of the Cre recombinase-loxP system to the gene-targeting in the mouse. The fusion with the ligand-binding domain of a mutant estrogen receptor made Cre recombinase inducible (Brocard et al., 1997). Recently, Kellendonk et al. (1999) reported the inducible Cremediated recombination in the brain by generating transgenic mice using a Cre recombinase-progesterone receptor fusion under the control of the calcium-calmodulin-dependent kinase II $\alpha$ or Thy-1 gene regulatory sequences. In these mice, RU486induced recombination were found in the hippocampus and the cortex, and drug-independent recombination, although to a lower extent, was observed in the striatum and olfactory bulbs. Using antiprogestin Org 31806 with lower anti-glucocorticoid activity (Kloosterboer et al., 1994), we successfully induced Cre recombinase in the cerebellar granule cell-specific manner. There was a weak recombination in the cerebellar granule cells of ECP25 line without induction. Thus, it is possible that CrePR protein may have a residual activity that mediates a low level of recombination accumulating in neurons with long life spans. Although the effects of progesterone receptor antagonists on brain functions remain to be examined, it is known that the male mice lacking the progesterone receptor develop normally (Lydon et al., 1995). Furthermore, the drug treatment is only transient, and one can test the effect of gene manipulation after clearance of antiprogestins.

The ECP25 strain will provide a valuable tool to investigate the physiological roles of cerebellar granule cell-mediated transmission and plasticity. The granule cells convey the motor and sensory information through parallel fibers into Purkinje cells in which integration of various cerebellar inputs take place. The synapses between the granule cell and Purkinje cell are central plastic sites in the cerebellum. Coactivation of parallel fiber and climbing fiber inputs leads to long-term depression of this synapse, which has been suggested to be the cellular basis of motor learning (Ito, 1989). Tetanic stimulation of parallel fibers, on the other hand, results in long-term potentiation of the synapse (Sakurai, 1987). The physiological significance of this plasticity is, however, poorly characterized (Storm et al., 1998). Infusion of an NMDA receptor antagonist in the cerebellum resulted in the persistent multiple innervation of Purkinje cells by climbing fibers
(Rabacchi et al., 1992). This finding implies that parallel fiber input from granule cells with high NMDA receptor channel activities may control the refinement of climbing fiber-Purkinje cell synapse formation during development. Furthermore, the strategy used to generate the ECP25 mouse line can be applicable to Purkinje cell by the use of GluR $\delta 2$ and L 7 gene promoters, which will make it possible to manipulate the molecules in both the presynaptic and postsynaptic cells of the parallel fiber-Purkinje cell synapse.

Finally, we produced the transgenic mouse line of C57BL/6 strain. It is well established that the genetic background affects the behaviors of mice, and among mouse strains, C57BL/6 performs well various learning behaviors (Owen et al., 1997). Thus, the ECP25 line would be useful for analyzing the effects of granule cell function on motor learning and memory and possible cognitive roles of the cerebellum.

\section{REFERENCES}

Aiba A, Kano M, Chen C, Stanton ME, Fox GD, Herrup K, Zwingman TA, Tonegawa S (1994) Deficient cerebellar long-term depression and impaired motor learning in mGluR1 mutant mice. Cell 79:377-388.

Albus JS (1971) A theory of cerebellar function. Math Biosci 10:25-61.

Altman J, Bayer SA (1997) Development of the cerebellar system. Boca Raton, FL: CRC.

Araki K, Araki M, Miyazaki J, Vassalli P (1995) Site-specific recombination of a transgene in fertilized eggs by transient expression of Cre recombinase. Proc Natl Acad Sci USA 92:160-164.

Bakker GH, Setyono-Han B, Portengen H, De Jong FH, Foekens JA, Klijn JGM (1990) Treatment of breast cancer with different antiprogestins: preclinical and clinical studies. J Steroid Biochem Mol Biol 37:789-794.

Brocard J, Warot X, Wendling O, Messaddeq N, Vonesch JL, Chambon P, Metzger D (1997) Spatio-temporally controlled site-specific somatic mutagenesis in the mouse. Proc Natl Acad Sci USA 94:14559-14563.

Capecchi MR (1989) Altering the genome by homologous recombination. Science 244:1288-1292.

Chomczynski P, Sacchi N (1987) Single-step method of RNA isolation by acid guanidinium thiocyanate-phenol-chloroform extraction. Anal Biochem 162:156-159.

Desmond JE, Fiez JA (1998) Neuroimaging studies of the cerebellum: language, learning and memory. Trends Cognit Sci 2:355-362.

De Zeeuw CI, Hansel C, Bian F, Koekkoek SKE, van Alphen AM, Linden DJ, Oberdick J (1998) Expression of a protein kinase C inhibitor in Purkinje cells blocks cerebellar LTD and adaptation of the vestibulo-ocular reflex. Neuron 20:495-508.

du Lac S, Raymond JL, Sejnowski TJ, Lisberger SG (1995) Learning and memory in the vestibulo-ocular reflex. Annu Rev Neurosci 18:409-441.

Gu H, Zou YR, Rajewsky K (1993) Independent control of immunoglobulin switch recombination at individual switch regions evidenced through Cre-loxP-mediated gene targeting. Cell 73:1155-1164.

Gu H, Marth JD, Orban PC, Mossmann H, Rajewsky K (1994) Deletion of a DNA polymerase $\beta$ gene segment in T cells using cell type-specific gene targeting. Science 265:103-106.

Ho SN, Hunt HD, Horton RM, Pullen JK, Pease LR (1989) Sitedirected mutagenesis by overlap extension using the polymerase chain reaction. Gene 77:51-59.

Ito M (1989) Long-term depression. Annu Rev Neurosci 12:85-102.

Ito M, Sakurai M, Tongroach P (1982) Climbing fibre-induced depression of both mossy fibre responsiveness and glutamate sensitivity of cerebellar Purkinje cells. J Physiol (Lond) 324:113-134.

Kalderon D, Roberts BL, Richardson WD, Smith AE (1984) A short amino acid sequence able to specify nuclear location. Cell 39:499-509.

Kano M, Hashimoto K, Kurihara H, Watanabe M, Inoue Y, Aiba A, Tonegawa S (1997) Persistent multiple climbing fiber innervation of cerebellar Purkinje cells in mice lacking mGluR1. Neuron 18:71-79.

Kashiwabuchi N, Ikeda K, Araki K, Hirano T, Shibuki K, Takayama C, Inoue Y, Kutsuwada T, Yagi T, Kang Y, Aizawa S, Mishina M (1995) Impairment of motor coordination, Purkinje cell synapse formation, and cerebellar long-term depression in GluR $\delta 2$ mutant mice. Cell $81: 245-252$ 
Katoh K, Takahashi Y, Hayashi S, Kondoh H (1987) Improved mammalian vectors for high expression of G418 resistance. Cell Struct Funct 12:575-580.

Kellendonk C, Tronche F, Monaghan AP, Angrand PO, Stewart F, Schütz G (1996) Regulation of Cre recombinase activity by the synthetic steroid RU 486. Nucleic Acids Res 24:1404-1411.

Kellendonk C, Tronche F, Casanova E, Anlag K, Opherk C, Schütz G (1999) Inducible site-specific recombination in the brain. J Mol Biol 285:175-182.

Kishimoto Y, Kawahara S, Suzuki M, Mori H, Mishina M, Kirino Y (1998) Impairment of classical eyeblink conditioning in GluR82deficient mice. Soc Neurosci Abstr 24:443.

Kloosterboer HJ, Deckers GH, Schoonen WGE (1994) Pharmacology of two new very selective antiprogestagens: Org 31710 and Org 31806. Hum Reprod [Suppl 1] 9:47-52.

Kothary R, Clapoff S, Darling S, Perry MD, Moran LA, Rossant J (1989) Inducible expression of an hsp68-lac Z hybrid gene in transgenic mice. Development 105:707-714.

Kutsuwada T, Kashiwabuchi N, Mori H, Sakimura K, Kushiya E, Araki K, Meguro H, Masaki H, Kumanishi T, Arakawa M, Mishina M (1992) Molecular diversity of the NMDA receptor channel. Nature 358:36-41.

Lydon JP, DeMayo FJ, Funk CR, Mani SK, Hughes AR, Montgomery Jr CA, Shyamala G, Conneely OM, O'Malley BW (1995) Mice lacking progesterone receptor exhibit pleiotropic reproductive abnormalities. Genes Dev 9:2266-2278.

Marr D (1969) A theory of cerebellar cortex. J Physiol (Lond) 202:437-470.

Maruyama IN, Brenner S (1992) A selective $\lambda$ phage cloning vector with automatic excision of the insert in a plasmid. Gene 120:135-141.

Mizushima S, Nagata S (1990) pEF-BOS, a powerful mammalian expression vector. Nucleic Acids Res 18:5322.

Monyer H, Sprengel R, Schoepfer R, Herb A, Higuchi M, Lomeli H, Burnashev N, Sakmann B, Seeburg PH (1992) Heteromeric NMDA receptors: molecular and functional distinction of subtypes. Science 256:1217-1221.

Mori H, Miyazaki Y, Morita T, Nitta H, Mishina M (1994) Different spatio-temporal expressions of three otx homeoprotein transcripts during zebrafish embryogenesis. Mol Brain Res 27:221-231.

Nagasawa M, Sakimura K, Mori KJ, Bedell MA, Copeland NG, Jenkins NA, Mishina M (1996) Gene structure and chromosomal localization of the mouse NMDA receptor channel subunits. Mol Brain Res 36:1-11.

Owen EH, Logue SF, Rasmussen DL, Wehner JM (1997) Assessment of learning by the Morris water task and fear conditioning in inbred mouse strains and F1 hybrids: implications of genetic background for single gene mutations and quantitative trait loci analyses. Neuroscience 80:1087-1099.
Rabacchi S, Bailly Y, Delhaye-Bouchaud N, Mariani J (1992) Involvement of the $N$-methyl-D-aspartate (NMDA) receptor in synapse elimination during cerebellar development. Science 256:1823-1825.

Racine RJ, Wilson DA, Gingell R, Sunderland D (1986) Long-term potentiation in the interpositus and vestibular nuclei in the rat. Exp Brain Res 63:158-162.

Sakurai M (1987) Synaptic modification of parallel fibre-Purkinje cell transmission in in vitro guinea-pig cerebellar slices. J Physiol (Lond) 394:463-480.

Shibuki K, Gomi H, Chen L, Bao S, Kim JJ, Wakatsuki H, Fujisaki T, Fujimoto K, Katoh A, Ikeda T, Chen C, Thompson RF, Itohara S (1996) Deficient cerebellar long-term depression, impaired eyeblink conditioning, and normal motor coordination in GFAP mutant mice. Neuron 16:587-599.

Storm DR, Hansel C, Hacker B, Parent A, Linden DJ (1998) Impaired cerebellar long-term potentiation in type I adenylyl cyclase mutant mice. Neuron 20:1199-1210.

Suchanek B, Seeburg PH, Sprengel R (1997) Tissue specific control regions of the $N$-methyl-D-aspartate receptor subunit NR2C promoter. Biol Chem 378:929-934.

Thach WT (1996) On the specific role of the cerebellum in motor learning and cognition: clues from PET activation and lesion studies in man. Behav Brain Sci 19:411-431.

Thach WT, Goodkin HP, Keating JG (1992) The cerebellum and the adaptive coordination of movement. Annu Rev Neurosci 15:403-442.

Thompson RF, Krupa DJ (1994) Organization of memory traces in the mammalian brain. Annu Rev Neurosci 17:519-549.

Tsien JZ, Chen DF, Gerber D, Tom C, Mercer EH, Anderson DJ, Mayford M, Kandel ER, Tonegawa S (1996) Subregion- and cell typerestricted gene knockout in mouse brain. Cell 87:1317-1326.

Vegeto E, Allan GF, Schrader WT, Tsai MJ, McDonnell DP, O’Malley BW (1992) The mechanism of RU486 antagonism is dependent on the conformation of the carboxy-terminal tail of the human progesterone receptor. Cell 69:703-713.

Watanabe M, Inoue Y, Sakimura K, Mishina M (1992) Developmental changes in distribution of NMDA receptor channel subunit mRNAs. NeuroReport 3:1138-1140.

Watanabe M, Inoue Y, Sakimura K, Mishina M (1993) Distinct distributions of five $N$-methyl-D-aspartate receptor channel subunit mRNAs in the forebrain. J Comp Neurol 338:377-390.

Watanabe M, Mishina M, Inoue Y (1994) Distinct spatiotemporal expressions of five NMDA receptor channel subunit mRNAs in the cerebellum. J Comp Neurol 343:513-519.

Yagi T, Nada S, Watanabe N, Tamemoto H, Kohmura N, Ikawa Y, Aizawa S (1993) A novel negative selection for homologous recombinants using diphtheria toxin A fragment gene. Anal Biochem 214:77-86. 